\title{
PREDIKSI MODEL FINANCIAL DISTRESS (KEBANGKRUTAN) PADA PERUSAHAAN RITEL BURSA EFEK DENGAN MODEL ALTMAN DAN SPRINGATE INDONESIA PERIODE 2012-2016
}

\author{
Husnil Barry \\ husnil.barry@bisnis.pnj.ac.id \\ Program Studi Administrasi Bisnis Terapan, Politeknik Negeri Jakarta
}

\begin{abstract}
ABSTRAK
Penelitian ini bertujuan untuk mengidentifikasi model kebangkuratn yang paling powerfull untuk perusahaan ritel di Indonesia dan memprediksi kondisi perusahaan yang akan mengalami kebangkrutan masa yang akan datang. Model yang digunakan dalam penelitian ini yaitu Altman ZScore dan Springate. Hasil dari model tersebut adalah dapat diketahui kondisi-kondisi perusahaan tersebut sehat atau diambang kebangkrutan. Data yang digunakan dalam penelitian ini berjumlah 25 perusahaan yang termasuk dalam industri ritel yang sudah listing di Bursa Efek Indonesia tahun 2012-2016.
\end{abstract}

Kata kunci: Altman, Springate, Financial Distress.

\begin{abstract}
This study aims to identify the most powerful disaster models for retail companies in Indonesia and to predict the condition of companies that will experience bankruptcy in the future. The model used in this study is Altman Z-Score and Springate. The results of the model are the conditions of the company, the health or whether they are on the verge of bankruptcy are identified. The data used in this was 25 companies retail industry that had been listed on the Indonesia Stock Exchange in 2012-2016.
\end{abstract}

Kata kunci: Altman, Springate, Financial Distress.

\section{PENDAHULUAN Latar Belakang}

Di Indonesia terdapat beberapa sektor ekonomi yang dapat menunjang perekonomian negara, salah satu diantaranya adalah sektor perdagangan. Badan Pusat Statistik (BPS) mencatat, konsumsi rumah tangga memiliki kontribusi yang paling tinggi dalam struktur pembangunan ekonomi, yakni sebesar 56,13\%, disusul oleh Pembentukan Modal Tetap Bruto (PMTB) atau investasi sebesar 32,16\%, dan ekspor sebesar 20,37\%. Hal tersebut dapat mengindikasikan bahwa sektor perdagangan adalah lahan yang bagus untuk menjalankan usaha.

Namun, perkembangan zaman yang telah memasuki era digital dan teknologi modern memaksa mengubah pola perilaku konsumen terhadap keputusan pembelian, dimana banyak bermunculan bisnis online yang mempermudah konsumennya mendapatkan apa yang mereka butuhkan.
Fenomena tersebut menyebabkan melemahnya pertumbuhan pada sektor perdagangan besar dan ecera (ritel). Selain itu, biaya produksi juga menjadi salah satu faktor yang cukup mempengaruhi melambatnya pertumbuhan keuangan perusahaan.

Menurut ketua umum Asosiasi Pengusaha Ritel Indonesia (Aprindo) Roy N. Mandey, pertumbuhan ritel sepanjang 2017 lalu hanya mencapai 3,65 persen. Angka tersebut merupakan yang terendah selama sepuluh tahun terakhir. Aprindo mengakui kinerja ritel modern termasuk yang bergerak dibidang pakaian, pada kuartal I tahun 2017 memburuk. Penyebabnya diketahui karena menurunnya daya beli masyarakat yang cukup drastis, yakni sekitar 10\%-12\%. Selain itu, menurut Badan Pusat Statisik (BPS) tingkat konsumsi rumah tangga nasional berada di level 4,95\% disepanjang 2017. Angka tersebut melambat jika dibandingkan dengan tahun 2016 yang tumbuh sebanyak 5,01\%. 
Berdasarkan data tersebut dapat disimpulkan penjualan ritel nasional pada tahun 2016-2017 hampir semua sektor mengalami penurunan kecuali pada sektor Supermarket/Minimarket. Melambatnya perekonomian domestik dan menurunnya daya beli masyarakat sangat mempengaruhi bisnis ritel di Indonesia. Hal tersebut dapat dilihat dari banyaknya perusahaan ritel yang dinyatakan pailit atau bangkrut dan maraknya perusahaan perdagangan besar yang menutup berbagai gerainya.

Dari data yang kami olah terdapat 21 gerai ritel yang tutup antara tahun 2013-2017. Jumlah tersebut dari 4 perusahaan besar yaitu PT Matahari Department Store Tbk., PT Mitra Adi Perkasa Tbk., PT GAP dan PT Ramayana.

\section{Permasalahan}

Dari latar belakang diatas terdapat dua permasalahan yaitu

1. Apakah model yang paling tepat (diantara dua model Altman Z-Score dan Springate) dalam memprediksi kebangkrutan pada sektor perdagangan di Indonesia?

2. Ada berapa dan perusahaan manasaja yang diidentifikasi menuju kebangkrutan dalam sector perdagangan?

\section{TUJUAN}

Berdasarkan uraian diatas maka tujuan dari penelitian ini adalah untuk menjawab pertanyaan sebagai berikut:

1. Analisis model yang memiliki tingkat akurasi paling tinggi (diantara dua model Altman Z-Score dan Springate) yaitu dalam memprediksi kebangkrutan pada sektor perdagangan di Indonesia

2. Perusahaan apa saja yang terindikasi mengalami financial distress.

Kontribusi dalam penelitian ini adalah memberikan wawasan dalam bidang investasi pasar modal khususnya risiko kebangrkutan sebuah saham sebaiknya dihindari oleh para investor.

\section{TINJAUAN PUSTAKA}

Penelitian ini didasarkan pada beberapa teori sebagai berikut.

Menurut Husen dan Pambekti, 2014 kebangkrutan yaitu situasi dimana kewajiban atau hutang perusahaan melebihi aset yang dimiliki oleh perusahaan. Ini terjadi karena modal kerja yang dimiliki oleh perusahaan sangatlah sedikit, perusahaan tidak mampu menggunakan sumber daya yang dimilikinya, perusahaan hanya memiliki cadangan kas yang relatif kecil, dan penjualan perusahaan jumlahnya kecil dan akibat terjadinya situasi pasar yang tidak menentu. Kebangkrutan tidak terjadi seketika atau dalam waktu yang singkat tapi memerlukan proses waktu, sehingga seharusnya perusahaan sudah dapat mengidentifikasi gejala-gejala kebangkrutan yang muncul. Kesulitan keuangan merupakan gejala awal dari proses kebangkrutan perusahaan. Haryetti, 2010 berpendapat banyak terjadi salah kaprah dalam hal financial distress dan bankruptcy. Faktanya Financial distress (kesulitan keuangan itu) adalah gejala awal atau indikator awal bahwa perusahaan akan mengalami kebangkrutan.

Prediksi kebangkrutan melalui financial distress merupakan isu yang menarik dan berguna untuk banyak kalangan, seperti pemilik perusahaan, investor, kreditor, dan pemerintah. Menurut alkhatib et all (2011) peringatan dini terhadap kebangkrutan perusahaan merupakah langkah preventif dalam mengurangi risiko perusahaan menuju kebangkrutan.

Dalam membuat model prediksi kebangkrutan diperlukan laporan tahunan atau annual report dari berbagai perusahaan). Laporan keuangan yang telah dipublikasi merupakan gambarn perusahaan saat ini dan prediksi kondisi keuangan perusahaan masa ynag akan datang. Menurut Sayari,2013 et all kesulitan keuangan merupakan tahapan terakhir dari penurunan kesehatan keuangan perusahaan.

Putra (2016) melakukan penelitian dengan judul "Perbandingan Prediksi Financial Distress dengan Menggunakan Model Altman, Springate, dan Ohlson". 
Penelitian tersebut mencoba membandingkan model Altman, Springate, dan Ohlson terhadap prediksi financial distress pada perusahaan tambang batubara yang terdaftar di Bursa Efek Indonesia periode tahun 2008-2014. Penelitian ini menggunakan pendekatan analisis diskriminan untuk menganalisis model Altman Z-Score dan Springate, sedangan model Ohlson menggunakan regresi logit untuk menganalis data. Hasil dari penelitian ini menunjukkan bahwa model Springate memiliki akurasi lebih baik dibandingkan dengan model Altman dan Ohlson.

Desmawati, Kamaliah, dan Wijaya (2016) melakukan penelitian dengan judul "Analisis Prediksi Kebangkrutan dengan Model Altman, Springate, Grover, dan Zmijewski pada Industri Manufaktur di BEI". Penelitian tersebut bertujuan untuk menentukan tingkat akurasi beberapa model dari prediktor kebangkrutan atau kesulitan keuangan. Hasil dari penelitian tersebut membuktikan bahwa model prediksi kebangkrutan Altman, Springate, Grover, dan Zmijewski tidak menunjukkan ketepatan dalam memprediksi kebangkrutan pada industri manufaktur di Indonesia. Hal tersebut disebabkan tingkat akurasi yang rendah yaitu dibawah 50 persen.

\section{PENELITIAN TERDAHULU}

Putra, Norita, dan Firli (2016) melakukan penelitian dengan judul "Prediksi Kebangkrutan dengan Menggunakan Model Altman Z-Score dan Zavgren". Penelitian tersebut dilakukan untuk mengetahui prediksi kebangkrutan berdasarkan model Altman dan Zavgren dan mencari model yang paling sesuai untuk digunakan dalam sektor batubara. Hasil dari penelitian tersebut menunjukkan hasil prediksi kebangkrutan dengan model Altman Z-Score dan Zavgren cenderung tidak stabil setiap tahunnya. Ketepatan prediksi kebangkrutan model Altman Z-Score sebesar 71,42\% dan model Zavgren sebesar 57,14\%.

Sondakh, Murni, dan Mandagie (2014) melakukan penelitian dengan judul "Analisis Potensi Kebangkrutan dengan Menggunakan Metode Altman Z-Score, Springate, dan Zmijewski pada Industri Perdagangan Ritel yang Terdaftar Di BEI
Periode 2009-2013". Penelitian tersebut menentukan prediksi kebangkrutan dengan menggunakan metode Altman, Springate, dan Zmijewski. Hasil dari penelitian tersebut menunjukkan terdapat tiga perusahaan yang berpotensi bangkrut dan berdasarkan perhitungan standar deviasi rata-rata, analisis Springate memiliki tingkat akurasi lebih tinggi.

Husein dan Pambekti (2014) melakukan penelitian "Keakuratan dari Model Altman, Springate, Zmijewski, dan Grover dalam Memprediksi Kesulitan Keuangan". Penelitian tersebut bertujuan untuk melakukan analisis tingkat akurasi model-model sebagai prediktor kesulitan keuangan. Penelitian ini menggunakan teknik analisis data non parametik statistik yaitu regresi logit dengan analisis deskriptif. Hasil penelitian tersebut menunjukkan bahwa model Altman, Springate, Zmijewski, dan Grover dapat digunakan untuk memprediksi kesulitan keuangan..

Berdasarkan penelitian terdahulu, diketahui bahwa peneliti menggunakan beberapa model prediksi untuk melakukan penelitian terhadap kesulitan keuangan (financial distress) hingga potensi kebangkrutan. Terdapat tiga penelitian yang menggunakan model Springate. Dua diantaranya mengemukakan bahwa Springate adalah model prediksi terbaik untuk memprediksi kesulitan keuangan untuk perusahaan yang bergerak dibidang tambang batubara dan ritel..

Berdasarkan adanya temuan hasil akurasi yang berbeda-beda pada setiap penelitian yang dilakukan peneliti dengan menggunakan berbagai model prediksi dan bidang perusahaan, peneliti hanya membatasi menggunakan dua model dari penelitian yang sering digunakan peneliti terdahulu dan menjadi prediktor terbaik dalam model kebangkrutan yaitu Altman Z-Score dan Springate Melalui penelitian ini akan terlihat pula perusahaan mana saja yang mengalami kesulitan keuangan dan berpotensi mengalami kebangkrutan 
METODOLOGI PENELITIAN Model Altman

$$
Z=1,2 X_{1}+1,4 X_{2}+3,3 X_{3}+0,6 X_{4}
$$

Dengan standar penilaian berikut ini:

$$
\begin{array}{lll}
\mathrm{Z} & >2,99 & =\text { Zona Aman } \\
1,81 & <\mathrm{Z}<2,99 & =\text { Zona Abu-Abu } \\
\mathrm{Z} & <1,81 & =\text { Zona Berbahaya }
\end{array}
$$

Pada tahun 1984, Altman melakukan penelitian kembali di berbagai Negara. Penelitian ini menggunakan berbagai perusahaan manufaktur yang tidak go public. Hasil dari penelitian tersebut menghasilkan rumus sebagai berikut:

$$
\begin{aligned}
& \begin{array}{l}
\mathrm{Z}=0,717 \mathrm{X} 1+0,847 \mathrm{X} 2+3,107 \mathrm{X} 3+ \\
0,420 \mathrm{X} 4+0,998 \mathrm{X} 5
\end{array} \\
& \mathrm{Z} \quad \text { = Nilai keseluruhan } \\
& \mathrm{X} 1 \quad=\text { Modal kerja terhadap total aset } \\
& \mathrm{X} 2 \quad=\text { Laba ditahan terhadap total aset } \\
& \mathrm{X} 3 \quad=\text { EBIT terhadap total asset } \\
& \mathrm{X} 4 \quad=\text { Nilai buku ekuitas terhadap nilai } \\
& \text { buku utang } \\
& \mathrm{X} 5 \quad=\text { Penjualan terhadap total asset }
\end{aligned}
$$

Dengan standar penilaian seperti berikut:

$$
\begin{aligned}
& \mathrm{Z}>2,9 \quad \text { = Zona Aman } \\
& 1,23<\mathrm{Z}<2,9 \quad=\text { Zona Abu-abu } \\
& \mathrm{Z}<1,23 \quad=\text { Zona Berbahaya }
\end{aligned}
$$

\section{Model Springate}

$$
Z=1,03 X_{1}+3,07 X_{2}+0,66 X_{3}+0,4 X_{4}
$$

\section{Keterangan :}

$\mathrm{Z} \quad=$ Nilai keseluruhan

$\mathrm{X}_{1} \quad=$ Modal kerja terhadap total aset

$\mathrm{X}_{2}=$ Laba sebelum bunga dan pajak (EBIT) terhadap utang lancar

$\mathrm{X}_{3} \quad=$ Laba sebelum pajak (EBT) terhadap utang lancar

$\mathrm{X}_{4}=$ Penjualan terhadap total aset

\footnotetext{
Hasil perhitungan dengan menggunakan rumus Springate, akan menghasilkan skor yang berbeda antara satu perusahaan dengan perusahaan lainnya. Skor tersebut harus dibandingkan dengan standar
}

penilaian berikut ini untuk menilai keberlangsungan hidup perusahaan tersebut:

1. $\mathrm{Z}>0,862$ dikategorikan sebagai perusahaan sehat.

2. $\mathrm{Z}<0,862$ dikategorikan perusahaan dalam kondisi kesulitan keuangan dan berpotensi mengalami kebangkrutan.

\section{Populasi dan Sampel}

Dalam penelitian ini data yang digunakan adalah sebagai berikut

A. Data emiten perusahaan ritel atau perdagangan periode 2012-2016. Sumber data berasal dari www.idx.co.id.

B. Data laporan keuangan atau annual report seluruh emiten yang sudah listing di Bursa Efek Indonesia periode 2012-2016.

Penelitian ini juga menerapkan beberapa kriteria pemilihan saham-saham yang akan digunakan untuk sampel, yaitu

1. Saham-saham tersebut telah listing di BEI minimal pada awal periode data dan tidak pernah delisting dari BEI selama periode data penelitian.

2. Data-data saham harus tersedia dalam berbagai publikasi baik media elektornik maupun media cetak.

3. Termasuk dalam kelompok saham industri ritel atau perdagangan.

4. Bukan perusahaan yang bergerak di bidang keuangan. Leverage pada perusahaan keuangan dan non keuangan sangatlah berbeda. Pada saham keuangan leverage cenderung tinggi. Sedangkan pada perusahaan non keuangan leverage yang tinggi berhubungan dengan distress Fama dan French (1992).

Alasan dasar pemilihan saham-saham yang tergabung dalam industri ritel sebagai sample, yaitu dalam 5 tahun terakhir dalam industri ritel terdapat 22 toko atau gerai yang tutup di Indonesia dari 4 perusahaan ternama yaitu PT Matahari Department Store, PT Mitra Adi Perkasa, PT GAP, dan PT Ramayana serta ada 5 perusahaan ritel yang bangkrut yaitu PT Courts Indonesia, PT Dayaindo Resources 
Internastional, PT Asia Natural Resources, 7 Eleven dan Distara

\section{HASIL PENELITIAN DAN PEMBAHASAN}

Hasil penelitian dan pembahasan menggunakan program Eviews 9.

\section{Hasil Penelitian}

Berdasarkan tabel dibawah, perusahaan yang terindikasi mengalami financial distress berdasarkan perhitungan rumus model prediktor adalah :

Rangkuman Perusahaan Mengalami Financial

\begin{tabular}{|l|l|l|l|}
\hline \multicolumn{5}{|c|}{ Distress } \\
TAHUN & KODE & ALTMAN & $\begin{array}{l}\text { SPRIN } \\
\text { GATE }\end{array}$ \\
\hline 2013 & INTA & -35.55 & 0.28 \\
\hline 2014 & INTA & -52.59 & 0.14 \\
\hline 2015 & INTA & -114.23 & -0.07 \\
\hline 2016 & INTA & -115.61 & -0.06 \\
\hline 2017 & INTA & -48.56 & -0.13 \\
\hline 2013 & KONI & 92.91 & 0.65 \\
\hline 2014 & KONI & 275.23 & 0.57 \\
\hline 2015 & KONI & -293.08 & 0.48 \\
\hline 2016 & KONI & -126.32 & 0.18 \\
\hline 2017 & KONI & -146.37 & 0.31 \\
\hline 2013 & OKAS & -73.33 & 0.38 \\
\hline 2014 & OKAS & -33.16 & 0.11 \\
\hline 2015 & OKAS & -13.41 & -0.45 \\
\hline 2016 & OKAS & -15.19 & -0.31 \\
\hline 2017 & OKAS & -16.82 & -0.13 \\
\hline 2013 & RIMO & -114.38 & -14.46 \\
\hline 2014 & RIMO & -85.01 & -10.73 \\
\hline 2015 & RIMO & -26.37 & -2.62 \\
\hline 2016 & RIMO & -28.61 & -1.87 \\
\hline 2017 & RIMO & 53.56 & 0.27 \\
\hline
\end{tabular}

Sumber: Data sekunder diolah, 2018

Berikut penjelasan 4 perusahaan mengenai alasan empat perusahaan tersebut mengalami kebangkrutan a. PT Intraco Penta Tbk (INTA)

PT Intraco Penta Tbk adalah penyedia solusi peralatan berat di Indonesia, selain itu INTA juga menyediakan kebutuhan-kebutuhan lain seperti Component Rebuilt Centre (CRC), persediaan suku cadang, dan konsinyasi kepada pelanggan untuk memastikan agar peralatan mereka bisa beroperasi secara maksimal. Sebanyak enam dari tujuh model yang digunakan penulis guna memprediksi financial distress menyatakan bahwa INTA dalam kondisi tidak aman.

Besaran jumlah kerugian perusahaan pada tahun 2013 sebesar Rp 242,631,000,000, walaupun terdapat kenaikan laba pada tahun berikutnya yakni $\mathrm{Rp}$ 49,596 tidak membuat INTA terbebas dari kondisi financial distress karena pada tahun 2015 hingga 2017 INTA masih mengalami fluktuasi kerugian. Kondisi tersebut dipengaruhi oleh proses restrukturisasi yang sedang dijalani salah dari anak perusahaan INTA yakni PT Intan Baruprana Finance Tbk (IBFN). Selain itu, EBITDA perusahaan turun $82 \%$ (year on year), dengan EBIT meningkat $1.096 \%$, faktor pemberatnya berada pada turunnya pendapatan dari bisnis pembiayaan. (Kontan, 2017)

b. PT Ancora Indonesia Resources Tbk (OKAS)

PT Ancora Indonesia Resources Tbk memiliki ruang lingkup kegiatan perusahaan pada pertambangan, perdagangan, pengangkutan, pertanian, industri, pembangunan dan jasa. Lima model prediktor menyatakan OKAS dalam kondisi financial distress. Kondisi tersebut didukung oleh fluktuasi kerugian yang dialami perusahaan tersebut dalam kurun waktu lima tahun seperti pada grafik berikut:

Dilansir dari Kontan.co.id (12/12/2017), pendapatan bersih pada tahun 2017 turun $7 \%$ bila dibandingkan tahun sebelumnya yaitu senilai US\$74.53 juta. Penyebab utama penurunan adalah akibat kinerja penjualan anak perusahaan yakni PT Multi Nitrotama Kimia (MNK) yang menurun, selain itu OKAS juga masih menanggung hutang kepada perbankan.

c. PT Perdana Bangun Pusaka (KONI) 
Perusahaan yang bergerak dibidang penjualan dan distribusi produk-produk fotografi ini, diprediksi mengalami kondisi financial distress berdasarkan perhitungan lima model yang digunakan peneliti.

Kondisi tersebut disebabkan oleh menurunnya jumlah permintaan konsumsi kertas fotografi setiap tahunnya. Direktur KONI, Rudy, dilansir dari tribunnews.com menyatakan bahwa perkembangan teknologi digital seperti kamera digital dan telfon genggam pintar (smartphone) sangat signifikan pengaruhnya karena foto-foto dapat disimpan dan tidak perlu dicetak kembali.

$\begin{array}{llll}\text { d. } & \text { Rimo International } & \text { Lestari } & \text { Tbk } \\ & \text { (RIMO) } & & \\ \text { Rimo International } & \text { Lestari } & \text { Tbk }\end{array}$ bergerak dibidang perdagangan umum yang menjual berbagai macam barang seperti pakaian, aksesoris, tas, sepatu, dan kosmetik melalui toko serba ada (department store). RIMO merupakan perusahaan yang berada di zona merah, karena tujuh model prediktor yang peneliti gunakan dalam memprediksi financial distress menyatakan bahwa RIMO mengalami kondisi financial distress atau berpontensi mengalami kebangkrutan.

Kondisi tersebut didukung oleh kerugian yang dialami perusahaan selama empat tahun berturut-turut, selain itu menurut Fauzian yang dilansir dari economy.okezone.com menyatakan bahwa kenaikan laba yang sangat signifikan terjadi karena perusahaan akan beralih menjalankan bisnis pada bidang properti. RIMO mendiversifikasikan usahanya kedalam bisnis properti sebagai strategi keluar dari kondisi financial distress dan menghindari kebangkrutan kebangkrutan. (Investasi Okezone, 2017)

\section{SIMPULAN}

Berdasarkan hasil analisis data dan pembahasan yang telah penulis uraikan sebelumnya, penulis dapat mengambil kesimpulan sebagai berikut:

a. Penelitian ini menggunakan dua model prediktor financial distress yaitu Altman, dan Springate b. Perusahaan yang terindikasi mengalami kondisi financial distress atau berpotensi bangkrut adalah:

1) PT Ancora Indonesia Resources Tbk (OKAS) sebanyak lima model prediktor memprediksi financial distress.

2) PT Perdana Bangun Pusaka Tbk (KONI) sebanyak lima model prediktor memprediksi financial distress.

3) PT Intraco Penta Tbk (INTA) sebanyak enam model prediktor memprediksi financial distress.

4) Rimo International Lestari Tbk (RIMO) sebanyak tujuh model prediktor memprediksi financial distress.

Bagi investor yang ingin menanamkan saham atau modalnya pada perusahaan yang mengalami financial distress tersebut, agar mempertimbangkan kembali keputusannya karena perusahaan tersebut memiliki risiko dan potensi kebangkrutan yang cukup tinggi.

\section{DAFTAR PUSTAKA}

Amihud, Yakov. (2002). Illiquidity and Stock Returns: Cross-section and Time series effect. Journal of Financial Markets 5, 2002,page 31-56

Brooks, Chrish. (2002). Introductory Econometrics For Finance. Cambridge: Cambridge University Press

Fama, Eugiene F., French, Kenneth. (2004). The Capital Asset Pricing Model: Theory and Evidence. Journal of Economic Perspective Volume 18 No 3, Summer 2004, page-64

Fama, Eugiene F., French, Kenneth. (2004). The Cross Section Of Expected Stock Return. Journal of Economic Perspective Volume 18 No 3, Summer 2004, page-64

Ross, Stephen., W, Randolph., dan Jordan, Bradford. (2007). Corporate Finance Fundamental. New York: McGrawHill.

Reilly, Frank K., Brown, Keitch. 2006. Investment Analysis and Portofolio Management $8^{\text {th }}$ edition: Thomson South Western 
Brigham, F. Eugene dan Michael C. Ehrhadt. 2005. Financial Management: Theory and Practice $11^{\text {th }}$ edition. United States of America: South-Western, part of The Thomson Corp.

Darsono dan Ashari. 2005. Pedoman Praktis Memahami Laporan Keuangan. Yogyakarta: Andi.

Ghozali, Imam. 2011. Aplikasi Analisis Multivariate Dengan Progaram SPSS. Semarang: BP UNDIP.

Hanafi, Mamduh M. 2007. Analisis Laporan Keuangan. Yogyakarta: UPP STIM YKPN.

Hanafi, Mamduh M dan Abdul Halim. 2012. Analisis Laporan Keuangan.
Yogyakarta: UPP STIM YKPN.

Harahap, Sofyan Syafri. 2010. Analisis Kritis Atas Laporan Keuangan. Jakarta: Rajawali Pers.

Indrianto, Nur dan Bambang Supomo. 2012. Metodologi Penelitian BisnisUntuk Akuntansi dan Manajemen. Yogyakarta: BPFE-Yogyakarta.

Kasmir. 2017. Analisis Laporan Keuangan. Jakarta: Rajawali Pers.

Munawir ,S. 2010. Analisa Laporan Keuangan. Yogyakarta: Liberty. 